\title{
Cost-benefit analysis of reservoir operation scenarios considering environmental flows for the lower stretch of the São Francisco River (Brazil)
}

\section{Análise de custo-benefício de cenários de operação de reservatórios considerando o hidrograma ambiental para o baixo curso do Rio São Francisco}

\author{
Micol Brambilla ${ }^{1}$, Andrea Sousa Fontes ${ }^{2}$ and Yvonilde Dantas Pinto Medeiros ${ }^{1}$ \\ ${ }^{1}$ Universidade Federal da Bahia, Salvador, BA, Brazil \\ ${ }^{2}$ Universidade Federal do Recôncavo da Bahia, Cruz das Almas, BA, Brazil \\ E-mails: brambilla.micol@gmail.com (MB), asfontes@gmail.com (ASF), yvonilde.medeiros@gmail.com (YDPM)
}

Received: September 20, 2016 - Revised: January 22, 2017 - Accepted: March 19, 2017

\begin{abstract}
Environmental water allocation consists in considering the environment as a licit user of water. The importance of meeting the environment's hydric necessities to assure ecosystem protection is recognized worldwide, however their practical implementation is restricted, requiring impact assessment of the implementation towards the other water users. In this context, this article aims to evaluate the financial impacts on the hydroelectric sector considering environmental flows as reservoir release restrictions. The case study is the lower course of the São Francisco River, a region that presents a strong social and environmental degradation of great importance for Brazilian energy system. The method used to achieve this goal contemplates the construction of reservoir operation scenarios, the mathematical modeling of the water system and the cost-benefit analysis for the energy sector. The simulation points out potential conflicts between the non-consumptive uses. Assessing the cost-benefit analyses for normal and dry periods, it turns out that the first leads to total financial losses for the energy sector, while the second to payoffs, enabling agreements between Brazil's energy generation and the implementation of environmental flows in the lower stretch of the São Francisco River.
\end{abstract}

Keywords: Environmental allocation of water; Implementation of environmental flows; Financial impact; Reservoir operation; Hydropower generation.

\section{RESUMO}

A alocação ambiental da água consiste em considerar o meio ambiente como lícito usuário da água. A importância em determinar as necessidades hídricas da água para proteção do ecossistema, é reconhecida mundialmente, entretanto as implementações práticas de vazões ambientais são restritas, necessitando da avaliação dos impactos dessa implementação nos demais usuários da água. Nesse contexto, o artigo objetiva avaliar o impacto econômico no setor elétrico considerando as vazões ambientais como restrição de escoamento a jusante dos reservatórios. O estudo de caso é o baixo curso do rio São Francisco, uma região que presenta uma degradação social e ambiental acentuada com extrema relevância para o sistema energético do Brasil. A metodologia adotada compreendeu a construção de cenários de operação de reservatórios, modelagem matemática do sistema hídrico e análise custo-benefício para o setor energético. A simulação aponta a possíveis conflitos entre os usos não consuntivos. Avaliando a análise custo-benefício para períodos normais e secos, os primeiros resultam em perdas financeiras totais para o setor elétrico, enquanto os segundos em ganhos totais, permitindo acordos entre a geração de energia e a implementação de vazões ambientais no baixo curso do rio São Francisco.

Palavras-chave: Alocação ambiental da água; Implementação de vazões ambientais; Impacto financeiro; Operação de reservatórios; Geração hidroelétrica. 


\section{INTRODUCTION}

Adequate watershed management requires structural and non-structural measures. Water allocation consists in a non-structural instrument that aims at an effective long term planning of water distribution among the watershed stake- holders. Complementary structural instruments are multi-purpose reservoirs. Reservoir operation rules aim to maximize the reservoirs' efficiency while covering all uses present in the corresponding basin. Criteria to meet the water uses interfere directly in water allocation strategies and reservoir operation rules. Non-consumptive uses, uses that do not need a water catchment, require most of the water available. Considering that they need different modes of reservoir operation, a big challenge is to find a compromise among these water users, to mitigate conflicts.

Only a few countries consider the environment as a user of water resources recognizing its water needs (DYSON et al., 2003; SOUZA et al., 2008), which change in time and space. The hydric needs of environments are internationally known as environmental flows and many conceptual studies have been done about this issue (POFF et al., 1997; O'KEEFFE, 2009; THARME, 2000; PAHL-WOSTL et al., 2013). Although their importance for the protection of ecosystems' processes and functions is well known, their implementation has been limited due to their encountering resistance in conservative ideas of water management strictly associated with direct human use.

Concerning implementation, studies have been done primarily analyzing the conflict between the necessity to attend to hydropower generation and environmental protection (BRAMBILLA, 2016), primarily because hydropower generation is the non-consumptive water use that produces the biggest revenues and therefore is normally privileged in the definition of the rules for the operation of reservoirs. The principal tools employed in these studies are allocation models and cost-benefit analysis and the most used analytical criteria are the losses in energy production or in revenues for the energy sector. Some of the results have highlighted the losses of the energy sector in modifying reservoir operation rules as an impact of the implementation of environmental flows (YANG et al., 2012; BOODOO et al., 2014). Other studies evidenced a possible compromise between attending to the energy sector and the environment (GÓMEZ et al., 2014; LIECHTI et al., 2015; BABEL et al., 2012; CAI et al., 2013). This article aims to evaluate the financial impacts on the hydroelectric sector due to environmental water allocation, considering the implementation of environmental flows.

\section{CASE STUDY AREA}

The Brazilian energy sector is peculiar, comprising four integrated subsystems that are together responsible for meeting the energy demand, as illustrated in Figure 1. Electricity planning is done on different levels, including individual power stations, subsystems, and the integrated system, with the assistance of the simulation and optimization models MSUI (ELETROBRAS, 2009), NEWAVE (CEPEL, 2013b) and SUSHI-O (CEPEL, 2013a) for long-term energy generation planning. The aim of Brazil's energy policy is to assure the service, offering the cheapest possible prices.

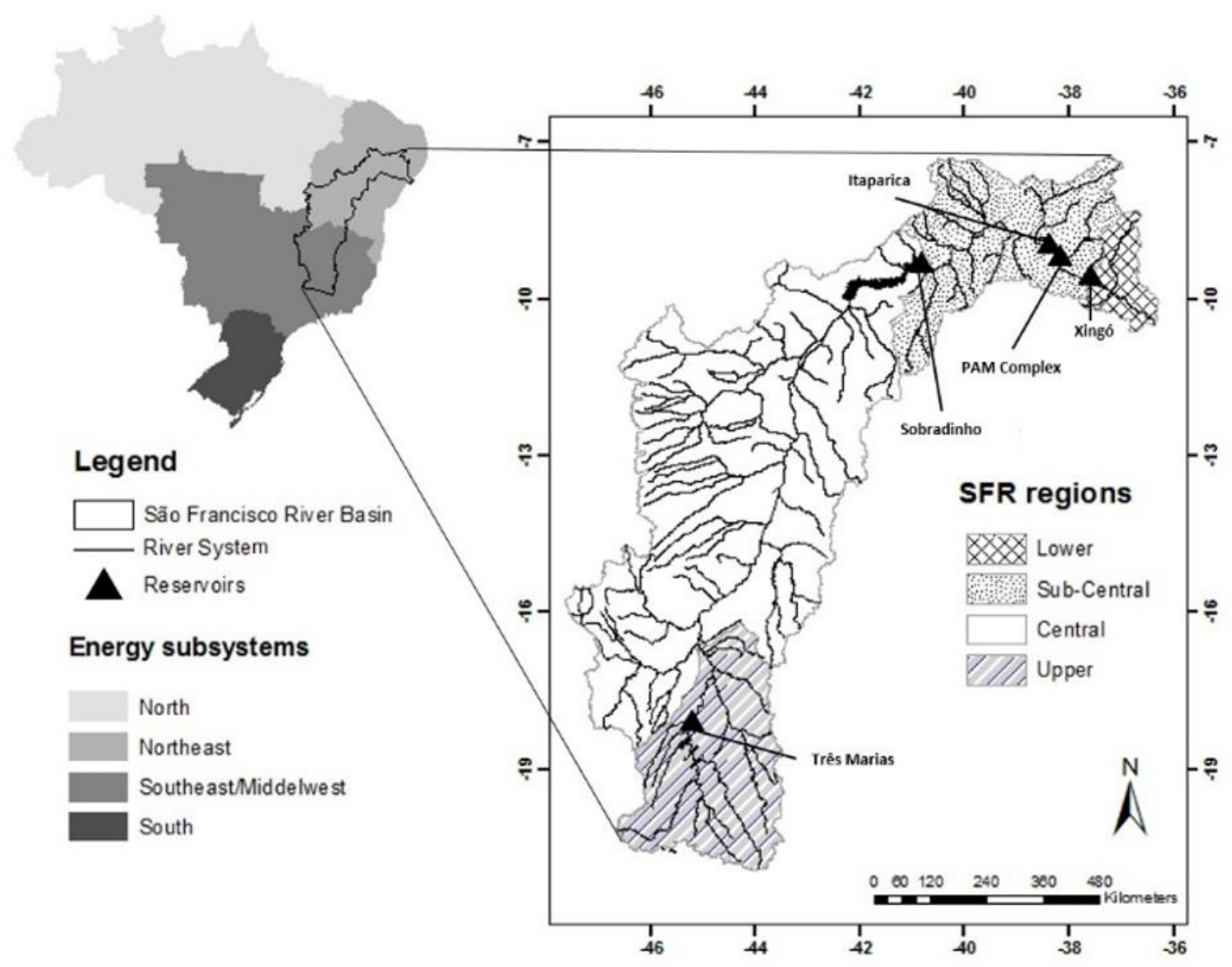

Figure 1. Brazil's energy subsystems and the São Francisco River basin. 
Nowadays, the generating capacity of the electricity matrix consists of $61 \%$ hydroelectricity, $28 \%$ thermoelectricity, and $6 \%$ wind energy. The Brazilian energy market is organized in auctions. Regularly, the difference between what is contracted and what is actually generated, transferred and consumed, is calculated and sold within the spot market (short-term market). The energy prices in the spot market (PSM) differ for each subsystem and load step, and are based on the energy's marginal cost of operation (MCO), namely the operative cost variation necessary to meet one additional MWh of demand employing the existing resources. The MCO integrates all the available sources in the electricity system and is directly influenced by hydrological conditions, energy demand, fuel prices, deficit cost, operation of new projects, and the availability of generation and transmission equipment.

The São Francisco River basin is of great importance for the Brazilian energy system. More than $90 \%$ of the installed hydroelectric capacity of the Northeast's subsystem is installed in this region.

Nevertheless, the São Francisco River represents the basin with the biggest fish biodiversity of Brazil's northeastern region,

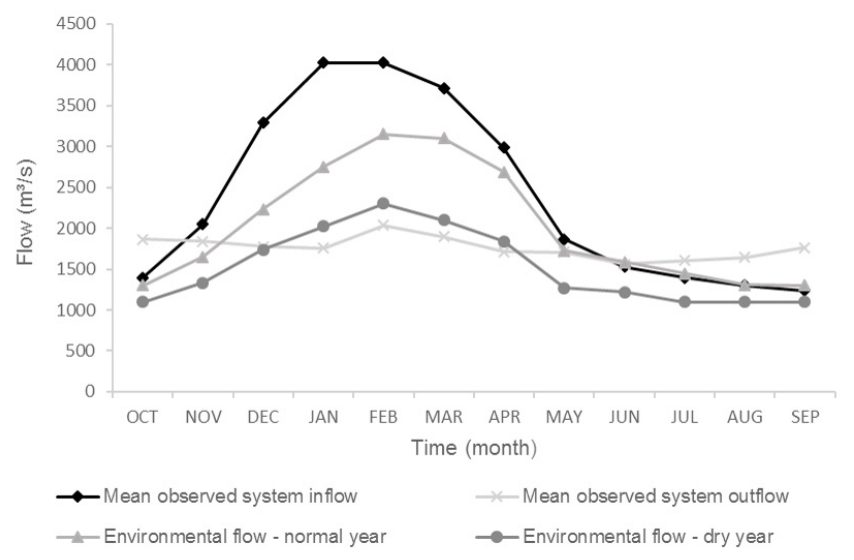

Figure 2. Seasonal distribution of historic mean of Sobradinho's reservoir inflow (1997-2015), reservoir cascade runoff (1995-2015) and environmental flows. which is harmed by the flow regulation caused by the dams present in the river: Sobradinho, Itaparica, Paulo Afonso-Moxotó Complex, and Xingó, as analyzed by the basin committee (CBHSF, 2004). To mitigate the effects of this dam regulation, environmental flows, considered mitigation measures that aim to meet the main features of the natural flow of the São Francisco River, for dry and normal years for the lower stretch of the river, were developed. So far, Sobradinho dam is the one with the main regularization effect determining the subsequent flow patterns and is therefore considered as starting point of the environmental flows analysis of the studied area. The methodology chosen was the Building Block Methodology (BBM), a holistic method based on the concept that some flows in the complete hydrological regime of a river are more important than others for maintaining river ecosystems, which can be identified and described in terms of its magnitude, duration, timing and frequency. These flows were obtained through hydrological, ecosystem and social analysis operated by experts from different disciplines (MEDEIROS et al., 2010). Figure 2 highlights the regularization effect of the dams and the seasonality of the proposed environmental flows, showing the seasonal distribution of the historic mean of Sobradinho reservoir inflow (1997-2015), reservoir cascade runoff (1995-2015) and the environmental flows.

Next, it is necessary to analyze the impacts on the São Francisco River water demands caused by the implementation of the proposed environmental flow. This study assesses the economic impacts, through a cost-benefit analysis, on the energy sector considering an environmental water allocation of the lower course of the São Francisco River.

\section{METHOD}

The method chosen to achieve this objective is divided into three steps: the construction of reservoir operation scenarios, the simulation of those scenarios, and a cost-benefit analysis to assess their financial impact on the energy sector. The steps are explained in detail in the following sub-chapters and represented schematically in the flow chart Figure 3 at the end of the chapter.
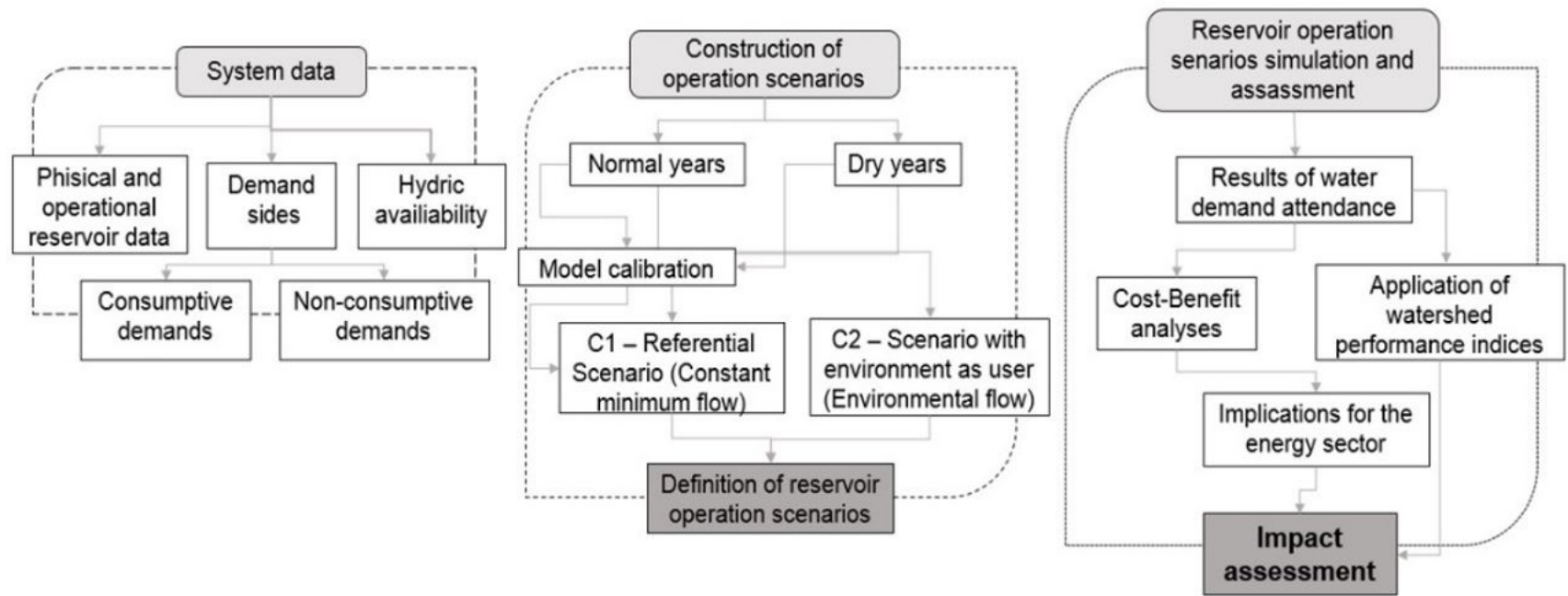

Figure 3. Flowchart of the method. 


\section{Construction of reservoir operation scenarios}

The method of scenario construction was determined to represent and compare reservoir operation alternatives. The two constructed scenarios differ in the reservoir minimum outflow restriction and represent two different types of water allocation:

- C1: Scenario 1 is the reference scenario and considers constant minimum flows (actual water allocation);

- C2: Scenario 2 is the scenario that integrates the environment as a water resource user and considers the proposed environmental flows as minimum flows (environmental water allocation).

These scenarios were separated into one normal and one dry period, determined within the historical series of 2000-2013 through reservoir-operated volumes. The normal period lasts from October 2004 until September 2007 and the dry period from October 2000 until September 2003.

With the purpose of exploring and comparing the results, two other periods were analyzed for the cost-benefit analysis: from October 2008 until September 2011, normal period, and from October 2012 until September 2015, dry period.

C1 assumes $1300 \mathrm{~m} 3 / \mathrm{s}$ as the minimum flow in the stretch between the downstream of Sobradinho dam and the river mouth for the normal period, and $1100 \mathrm{~m} 3 / \mathrm{s}$ for the dry period, while $\mathrm{C} 2$ assumes the normal year's environmental flow for the normal periods and the dry year's environmental flow for the dry periods.

\section{Simulation of the operation scenarios with the allocation model WEAP}

The Water Evolution and Planning System (WEAP) is a decision support system for integrated water resources planning and management based on mathematical simulation. This system was here chosen as a tool to simulate and compare the two operation alternatives.

The WEAP model was developed by the Stockholm Environment Institute (SEI, 2011). A user-friendly and intuitive model designed to easily compute scenario analysis and enter environmental hydric requirements, it bases the allocation on the mass balance in every node, ruled by demand priority determination.

The possibility to determine the time discretization of the simulation, decide its starting data, consider the hydrological situation of the basin (very dry year, dry year, normal year, wet year, very wet year), and to insert restrictions are some extremely useful tools for the aim of this analysis.

The data needed to compile the allocation model are the reservoir inflows, the physical and operational characteristics of the reservoirs, the system losses, and the consumptive and non-consumptive demand sides.

With the aim of minimizing the uncertainties, the model was adjusted to the real system through a calibration of the operating volume in Sobradinho reservoir and its outflows. Statistical tests were conducted to assist the calibration: Pearson's correlation,
Nash-Sutcliffe efficiency (NSE) coefficient, and Percent Bias (PBIAS) coefficient.

\section{Cost-benefit analysis}

The first step of the cost-benefit analysis consists in applying performance indexes of the water resource system, Reliability, Resilience and Vulnerability (HASHIMOTO et al., 1982) to analyze the possible conflicts between the non-consumptive demand sides. The indicators show the probability of the system to meet a water demand in time-domain (Reliability), the delay of a system in recover from a coverage failure (Resilience), and the volumetric magnitude of the failure (Vulnerability).

$$
\operatorname{Rel}=\frac{1}{K} \sum_{j=1}^{K} Z_{i}
$$

$\operatorname{Res}=\left[\frac{1}{M_{i}} \sum_{j=1}^{M} d_{i}\right]^{-1}$

$V u l=\frac{\sum_{j=1}^{M} S_{i}}{\sum_{j=1}^{K} D_{i}} * 100$

where $K$ is the total number of months, and $Z_{i}=1$ when the water demand is attended and $Z_{i}=0$ if the demand is not attended; $M_{i}$ is the occurrence of unsatisfactory attended demands and $d_{i}$ is the duration of coverage failure; $S_{i}$ is the volume of the coverage failure and $D_{i}$ is the total volume of the demand.

The Reliability values adopted to indicate a satisfactory result are $100 \%$ for the minimum flow requirement, considered as a restriction, $95 \%$ for hydroelectric referential generation, same range of error considered by the Brazilian energy sector, and 90\% for the minimum flow requirement for navigation, range of error considered acceptable in some Brazilian states.

The second step consists in identifying the financial gains and losses for the electricity sector considering the environmental flows as minimum flows. The revenue variance is computed by multiplying the difference in energy generation between $\mathrm{C} 2$ and $\mathrm{C} 1$ with the energy price as follows:

$$
\Delta \Pi_{C 1-C 2}=\left(E_{C 2}-E_{C 1}\right) * P S M_{\text {real }}
$$

where $E_{C 1}$ is the energy generated in $C 1$ and $E_{C 2}$ is the energy generated in C2 in MWh; $P S M_{\text {real }}$ is the real energy price; $\Delta \Pi_{C 1-C 2}$ is the difference in revenue resulting from diverse minimum flows restrictions in US\$.

The energy generation $E$ is function of elevation head $H$ and flow $Q$.

$$
E=f(H, Q)
$$

For maintaining the validity of the energy prices in current days, the real prices adopted were obtained through the multiplication of the current energy prices with the inflation rates as follows:

$$
\begin{aligned}
& P S M_{\text {real }}=P S M_{\text {current }}(x) * C_{\mathrm{I}}(x) \\
& C_{I}(x)=\frac{I_{I G P-M}(x)}{100}+1
\end{aligned}
$$


where $P S M_{\text {current }}(x)$ is the current energy price for period $\mathrm{x}$ and $C_{I}(x)$ is the multiplication coefficient determined through the inflation in $\%, I_{I G P-M}(x)$, of the period x to December 2015.

The $I_{I G P-M}$ is the inflation index for the general market prices provided by the Getúlio Vargas Foundation.

A flow chart of the method is presented in Figure 3.

\section{RESULTS}

\section{Model calibration}

The representation system through the WEAP model was adjusted to the actual operating system. For this purpose, different alternatives in water demand coverage, priority determination, and simulation period were tested. Thus, a simplified representation of the system was defined including only the principal channel and considering consumptive uses as restrictions, and therefore deducted from the inflow of the first reservoir. The first reservoir considered in the simulation is Sobradinho, the biggest regulation reservoir of the basin and the first hydroelectric power plant of the São Francisco cascade integrated in the Northeast's energy subsystem.

Comparing the observed and simulated volumes of Sobradinho reservoir and the observed and simulated flows downstream of this reservoir, the best adjustment found assigned the maximum priority to the minimum flow requirement, priority two for energy generation, and priority three for water storage in the reservoirs. This evidences that reservoir operation is done principally to meet the energy sector's requirements.

Initially, a normal period calibration was performed. The results of the statistical tests show a satisfactory adjustment of the stored volume of the Sobradinho reservoir, with a Pearson's correlation of 0.99 and NSE coefficient results indicating a very good correlation between simulated and observed reservoir values. The negative value of the PBIAS coefficient indicates a slight overestimation of simulated values. The outcomes of the flow comparison are 0.90 for Pearson's correlation, a result for NSE coefficient that indicates a good correspondence of the simulated with the observed values, and a PBIAS coefficient result that indicates a very good correlation of the series with an overestimation of the simulated values.

Applying the statistical tests to a dry period calibration analysis, there results a satisfactory correlation for the storage volumes in Sobradinho reservoir and a good correlation for outflows from Sobradinho dam. For storage volumes, Pearson's coefficient shows a good correlation (PEARSON=0.97). Although the NSE and PBIAS indices turned out to be insufficient and satisfactory, this was considered the best possible adjustment for the simplified representation. The comparison of the flow series displays good results with Pearson's coefficient of 0.87 and the values for the NSE and PBIAS indicators being good and very good. The negative values of the PBIAS indicate an overestimation of the simulated series for the storage volumes, as well as for the flows downstream of Sobradinho dam.

Considering these results, the WEAP model provides an efficient tool with a satisfactory representation of the operation of the São Francisco River, despite the simplified representation of the system. Nevertheless, by performing the simulation the investigation highlights an overestimation of the water availability, explainable through an underestimation of the assumed values of the system losses, and the illicit, and so not registered, water catchments.

\section{Scenario simulation and conflict analysis}

Implementing the considerations derived from the model adjustment to the simulation of $\mathrm{C} 1$ and $\mathrm{C} 2$, there arises two different operation cases. In general, the $\mathrm{C} 2$ flow behavior, and consequently the electricity generation, have an accentuated seasonality. Figure 4 illustrates the flow behavior downstream from Xingó dam for (a) normal years and (b) dry years.

A water shortage can be observed around October 2006 for $\mathrm{C} 2$, ascribable to the high mean value of the environmental flow for normal yeas, $2020 \mathrm{~m}^{3} / \mathrm{s}$, combined with the end of the dry months where the reservoir presents the lowest elevations.

The C2 minimum flow pattern also results in reduced stored volumes in the two principal reservoirs, Sobradinho and Itaparica, reflected in their water elevation. Consequently, hydroelectric generation decreases, as hydroelectric generation is directly proportional to water head. Table 1 shows the results of water resource system performance indicators applied to the simulated water demands coverage results for (a) the normal period and (b) the dry period.
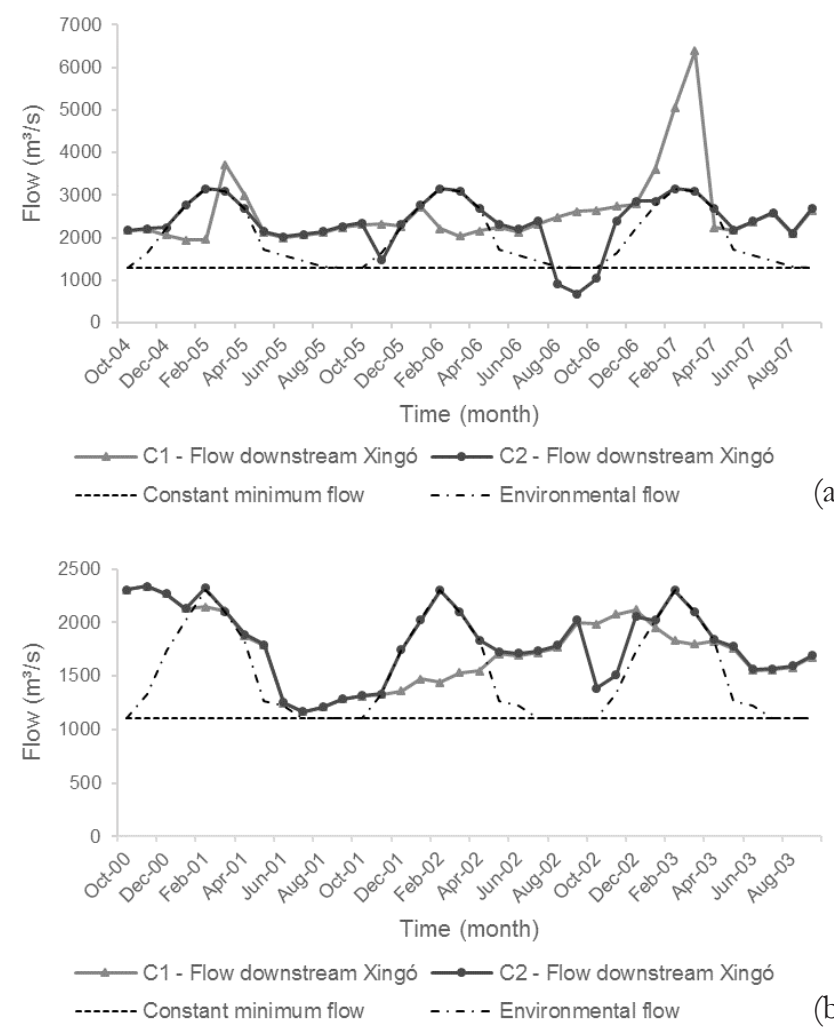

Figure 4. Simulated flows downstream of Xingó dam and minimum flow requirements for C1 and C2 for (a) normal period and (b) dry period. 
Considering the ranges of the reliability values adopted for analyzing the acceptability of the coverage of the demands, C1 for normal years meets all three demands, thus strengthening the calibration results, which indicated a good performance of the real system. On the contrary, $\mathrm{C} 2$ has difficulties in meeting the demands. The minimum flow and navigation requirements show similar results, with a reliability of $88.9 \%$, resilience of 0.5 , which means a moderately fast recovery from coverage failure, and volumetric reliabilities of approximately $92 \%$. Energy demand coverage also presents unsatisfactory results with a time-domain reliability of $86.1 \%$, vulnerability of almost $8 \%$, and a moderately low resilience index.

C1 simulation for dry years meets satisfactorily the analyzed demands, having a $91.7 \%$. reliability for navigation. Resilience shows a slow recovery from failure and the vulnerability shows a very small volumetric failure. The same results for navigation demand are shown for C2, Table 1b. This result is the consequence of a minimum flow requirement of $1100 \mathrm{~m}^{3} / \mathrm{s}$ for $\mathrm{C} 1$ and minimum values of environmental flow for dry years newly set at $1100 \mathrm{~m}^{3} / \mathrm{s}$ while the navigation requirement is of $1300 \mathrm{~m}^{3} / \mathrm{s}$. C2 also presents a failure in covering the energy demand, with small errors in the time and volumetric domains.

The system performance indicators highlight problems in meeting non-consumptive demands during the normal years for C2. This behavior is attributable to the high values of the normal year's environmental flow, with a mean value of $2020 \mathrm{~m}^{3} / \mathrm{s}$, approximately $500 \mathrm{~m}^{3} / \mathrm{s}$ higher than the mean value for dry year's environmental flow. Therefore, the implementation of more restrictive flows provokes possible conflicts between the watershed users, enhancing the necessity of negotiations to review the São Francisco River water allocation. A strategy that should be analyzed is to implement the less restrictive environmental flow for all hydrological and operational conditions first.

\section{Cost-benefit analysis}

A cost-benefit analysis to detect financial gains and losses is applied, restricted to the energy sector. The deficits and surpluses in hydroelectric generation of $\mathrm{C} 2$ in relation to $\mathrm{C} 1$ are multiplied by the spot market energy prices to determine the direct costs and benefits for the sector. For the study, the spot market energy prices are considered fixed for $\mathrm{C} 1$ and $\mathrm{C} 2$, although knowing that
PSM as function of MCO would vary with the alteration of São Francisco River reservoir operation.

Figure 5 shows the energy differences.

Both periods have excesses and deficiencies, whereas the first period shows more failures, and vice versa for the dry years.

To determine the effective impact on the energy sector, the current energy prices of the spot market for the simulated years were adjusted by market inflation indexes to December 2015, using $I_{I G P-M}$.

By means of the multiplication of the energy deficits and surpluses by the real energy prices, one obtains the annual costs and benefits as shown in Table $2 \mathrm{a}$.

With the purpose of exploring the results, two other periods were analyzed. The results are illustrated in Table $2 \mathrm{~b}$.

This second simulation presents overall higher values. Since 2012, Brazilian energy prices, principally for Northeast's
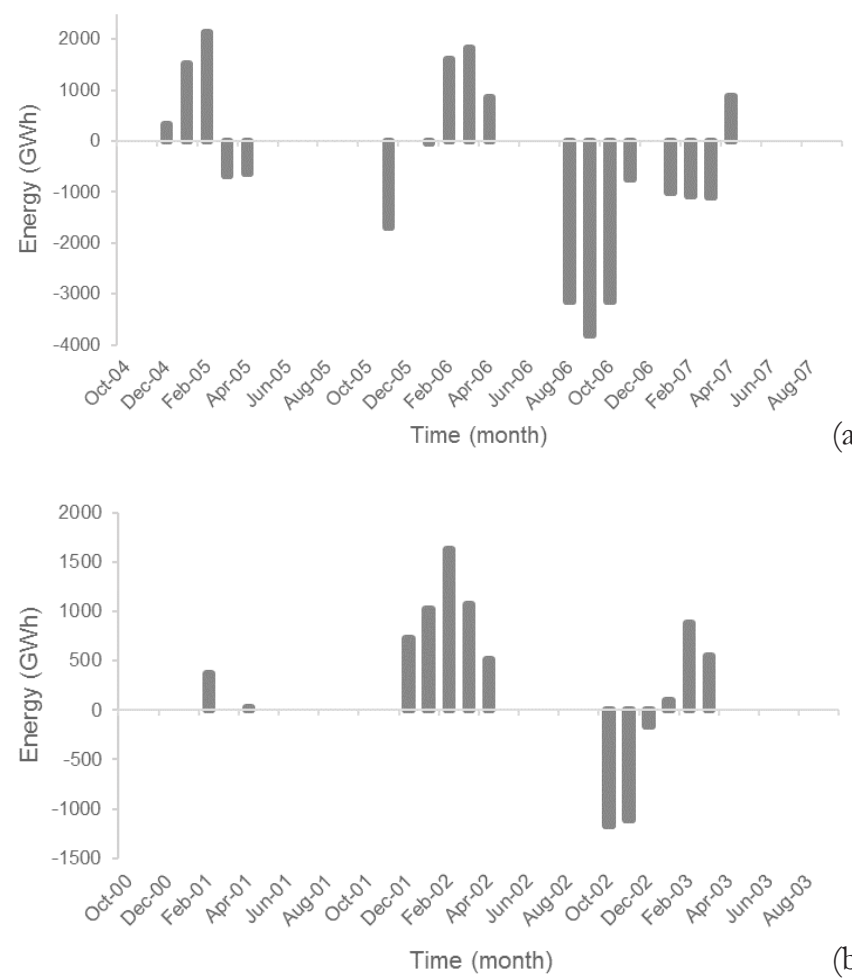

Figure 5. Difference in energy generation between C2 and C1 for (a) normal period and (b) dry period.

Table 1. Water resource system performance indicators applied to the simulation results of the non-consumptive demand sides coverage of C1 and C2 for (a) normal period (2005-2007) and (b) dry period (2001-2003).

\begin{tabular}{|c|c|c|c|c|c|c|}
\cline { 2 - 7 } \multicolumn{1}{c|}{} & \multicolumn{3}{c|}{ C1 } & \multicolumn{3}{c|}{ C2 } \\
\cline { 2 - 8 } \multicolumn{1}{c|}{} & Min. Flow & Energy & Navigation & Min. Flow & Energy & Navigation \\
\hline Reliability (\%) & 100 & 100 & 100 & 88.9 & 86.1 & 88.9 \\
\hline Resilience & & & & 0.5 & 0.4 & 0.5 \\
\hline Vulnerability (\%) & & & & 2.0 & 7.7 & 1.9 \\
\hline
\end{tabular}

\begin{tabular}{|l|c|c|c|c|c|c|}
\cline { 2 - 7 } \multicolumn{1}{c|}{} & \multicolumn{3}{c|}{ C1 } & \multicolumn{3}{c|}{ C2 } \\
\cline { 2 - 8 } \multicolumn{1}{c|}{} & Min. Flow & Energy & Navigation & Min. Flow & Energy & Navigation \\
\hline Reliability (\%) & 100 & 100 & 91.7 & 100 & 95.8 & 91.7 \\
\hline Resilience & & & 0.3 & & 0.5 & 0.3 \\
\hline Vulnerability (\%) & & 0.6 & & 1.5 & 0.6 \\
\hline
\end{tabular}


Brambilla et al.

Table 2. Annual costs and benefits for the energy sector caused by implementation of environmental flows (a) analyzed periods and (b) comparing periods.

\begin{tabular}{|l|c|c|}
\cline { 2 - 3 } \multicolumn{1}{c|}{} & Annual costs in (US\$ M) & Annual benefits in (US\$ M) \\
\hline Dry period (2001-2003) & 2.83 & 653.94 \\
\hline Normal period (2005-2007) & 194.85 & 64.29 \\
\hline
\end{tabular}

\begin{tabular}{|l|c|c|}
\cline { 2 - 3 } \multicolumn{1}{c|}{} & Annual costs in (US\$ M) & Annual benefits in (US\$ M) \\
\hline Dry period (2013-2015) & 168.77 & 1219.11 \\
\hline Normal period (2009-2011) & 338.67 & 172.24 \\
\hline
\end{tabular}

subsystem, have increased drastically because of limited hydrological availability. Indeed, as alternative sources to hydroelectric power plants, Brazil's energy sector has adopted thermo-electrical ones, which incur higher generation costs. It also becomes clear that the results of the cost-benefit analysis through this method vary, depending on the intrinsic and extrinsic characteristics of the scenario involved, intended as the referential scenario.

Through a balance of costs and benefits, an affirmation about how much the energy sector would lose or gain by implementing the proposed environmental flows can be made. In general, the benefits during the dry periods are higher than the costs, and vice versa for the normal years. This is ascribable to the fact that the mean outflow of Xingó dam in C2 compared to C1 is lower during normal periods and higher during dry periods achieving in normal years negative balances and vice versa in dry years. Additionally, the flow factor in this case affects more the energy production than the water elevation does (see Equation 5).

This results in total losses of US\$130.56 M for the first normal period simulated (2005-2007) and US\$166.43 M for the second one (2009-2011). Observing the dry years, the payoff for the first simulation is about US\$ 651.11 M (2001-2003) and US\$1050.34 M for the second one (2013-2015). This elucidates that reservoirs operating with more restrictive minimum flows, as the environmental flows considered for normal years, yield losses for the energy sector. In contrast, when implementing less restrictive environmental flows, the impacts for the energy sector are positive. The overestimation of water availability in the simulation leads to extremely favorable results for the implementation of environmental flows. Considering this misrepresentation, the gains should amount to smaller values, while the losses to bigger values.

\section{CONCLUSIONS}

The results of the performance indicators point to the necessity of negotiations between the non-consumptive uses when environmental flows are implemented in the studied region. However, the implementation of such flows solves some of the existing conflicts, such as between the energy sector and the riparian communities. A sustainable water allocation should integrate the environment as a water resource user with the aim to protect the aquatic ecosystem and allowing it to develop its processes and functions.

The cost-benefit analysis showed that the results depend on the characteristics of the considered scenario. Nevertheless, it can be stated that the implementation of environmental flows in the lower stretch of the São Francisco River would provide surpluses and deficits in the generation of energy in the Northeast.
Furthermore, the analysis shows that less restrictive environmental flows, the ones for dry years, lead to more energy surpluses than deficiencies. Balancing the costs and benefits in the simulated normal periods, where more restrictive environmental flows were considered, indicated the existence of financial losses, whereas in the dry periods, there were financial payoffs for the energy sector. In this context, Brazil's integrated energy system is profitable, because energy can be distributed between the subsystems, depending on the electricity demand and the energy prices. Nevertheless, it is to be understood that the implementation of environmental flows in the lower course of the São Francisco River will decrease the assured energy of the subsystem. The fact that assured energy is one of Brazil's energy policy pillars means that alternative technologies capable of storing energy are necessary, such as thermo-electrical, hydro-electrical, and nuclear power plants. These technologies are normally associated with high environmental impacts. Embracing a broader perspective, it is interesting to analyze renewable energy sources with a complementary seasonality to that of Sobradinhos' inflows. Another avenue that should be explored is Brazil's leeway in increasing the efficiency of the generation, distribution, and consumption, as a possibility to recover the energy losses caused by environmental flows.

It is also important to recognize the importance of environmental water allocation. Although the energy sector has several choices of energy sources, for most of the other users of water resources, water is the only possible choice. Furthermore, non-consumptive uses, like navigation or environment protection, can only avail themselves of the water in that very same ecosystem.

The current operation of the reservoir system of the lower stretch of the São Francisco River privileges sectors considered as being a priority, such as human, industrial, and energy supply, while other uses are considered secondary, like subsistence irrigation and fishery. Specifically, ecosystem protection is not integrated in the São Francisco River basin allocation, which contributes to a deep environmental degradation and alteration of the ecosystem components, processes and functions. This study showed that a possible water resources management strategy can include the initial implementation of environmental flows for dry years in all periods. Hence, there arises the necessity to analyze this possibility.

\section{ACKNOWLEDGEMENTS}

The study reported here was funded by FINEP and CNPq as part of the subproject AIHA-Avaliacão dos Impactos da Implantcão do Hidrograma Ambiental (Impacts assessment of environmental flows implementation) included in the HIDROECO project (MCT/FINEP CT-HIDRO 01/2010). Special acknowledgements to the São Francisco River Basin Committee. 


\section{REFERENCES}

BABEL, M. S.; DINH, C. N.; MULLICK, M. R. A.; NANDURI, U. V. Operation of a hydropower system considering environmental flow requirements: a case study in La Nga river basin, Vietnam. Journal of Hydro-environment Research, v. 6, n. 1, p. 63-73, 2012. http:// dx.doi.org/10.1016/j.jher.2011.05.006.

BOODOO, K. S.; MCCLAIN, M. E.; UPEGUI, J. J. V.; LÓPEZ, O. L. O. Impacts of implementation of Colombian environmental flow methodologies on the flow regime and hydropower production of the Chinchiná River, Colombia. Ecobydrology \& Hydrobiology, v. 14, n. 4, p. 267-284, 2014. http://dx.doi.org/10.1016/j.ecohyd.2014.07.001.

BRAMBILLA, M. Análise econômica de cenários de operação de reservatórios considerando o bidrograma ambiental para o baixo curso do rio São Francisco. 2016. $157 \mathrm{f}$. Dissertation (Master's thesis), Department of Environmental Engineering, Federal University of Bahia, Salvador, 2016.

CAI, W.; ZHANG, L.; ZHU, X.; ZHANG, A.; YIN, J.; WANG, H. Optimized reservoir operation to balance human and environmental requirements: a case study for the Three Gorges and Gezhouba Dams, Yangtze River basin, China. Ecological Informatics, v. 18, p. 4048, 2013. http:/ /dx.doi.org/10.1016/j.ecoinf.2013.06.009.

CBHSF - COMITÊ DA BACIA HIDROGRÁFICA DO RIO SÃO FRANCISCO. Plano Decenal de Recursos Hídricos da Bacia Hidrográfica do Rio São Francisco: PBHSF (2004-2013). Belo Horizonte, 2004. Resumo Executivo.

CEPEL_CENTRO DE PESQUISAS DE ENERGIA ELÉTRICA. SUISHI-O: modelo de simulação a usinas individualizadas de subsistemas hidrotérmicos interligados. Rio de Janeiro; 2013 a. Available from: <http://www.cepel.br/main.jsp?lumPageId=21 CF888C4A1692FF014A784FD2AE60D0\&lumS=cepelinternet. produto $\&$ CodProduto $=4028$ B88136E3DBC70136E40CF8E52 11E\&lumItemId=4028B88136E3DBC70136E40CF8FB2120>. Access on: feb. 2016.

CEPEL - CENTRO DE PESQUISAS DE ENERGIA ELÉTRICA. Modelo estratégico de geração bidrotérmica a subsistemas equivalentes: NEWAVE: guia de usuário. Versão 17.5.3. Rio de Janeiro; 2013b.

DYSON, M.; BERGKAMP, G.; SCANLON, J. The essentials of environmental flows. Gland: International Union for Conservation of Nature and Natural Resources; 2003. 134 p.

ELETROBRAS. Modelo de Simulação a Usinas Individualizadas (MSUI): guia de usuário. Versão 3.2. Rio de Janeiro; 2009.

GÓMEZ, C. M.; PÉREZ-BLANCO, C. D.; BATALLA, R. J. Tradeoffs in river restoration: Flushing flows vs. hydropower generation in the Lower Ebro River, Spain. Journal of Hydrology, v. 518, p. 130-139, 2014. http://dx.doi.org/10.1016/j.jhydrol.2013.08.029.

HASHIMOTO, T.; STEDINGER, J.; LOUCKS, D. P. Reliability, resilience and vulnerability criteria for water resource system performance evaluation. Water Resources Research, v. 18, n. 1, p. 14-26, 1982. http://dx.doi.org/10.1029/WR018i001p00014.

LIECHTI, T. C.; MATOS, J. P.; BOILLAT, J. L.; SCHLEISS, A. $\mathrm{J}$. Influence of hydropower development on flow regime in the zambezi river basin for different scenarios of environmental flows. Water Resources Management, v. 29, n. 3, p. 731-747, 2015. http:// dx.doi.org/10.1007/s11269-014-0838-1.

MEDEIROS, Y. D. P.; PINTO, I. M.; STIFELMAN, G. M.; FARIA, A. S. F.; PELLI, J. C. S.; RODRIGUES, R. F.; SILVA, E. R.; COSTA, T.; BOCCACIO, M. X.; SILVA, E. B. G. Projeto 3.1: participação social no processo de alocação de água, no baixo curso do Rio São Francisco. In: UNIVERSIDADE FEDERAL DA BAHIA. Estudo do regime de vazão ecológica para o Baixo curso do Rio São Francisco: uma abordagem multicriterial. Salvador, 2010. Relatório Técnico CNPQ/ CT-HIDRO.

O'KEEFFE, J. Sustaining river ecosystems: balancing use and protection. Progress in Physical Geography, v. 33, n. 3, p. 339-357, 2009. http://dx.doi.org/10.1177/0309133309342645.

PAHL-WOSTL, C.; ARTHINGTON, A.; BOGARDI, J.; BUNN, S. E.; HOFF, H.; LEBEL, L.; NIKITINA, E.; PALMER, M.; POFF, L. R. N.; RICHARDS, K.; SCHLÜTER, M.; SCHULZE, R.; ST-HILAIRE, A.; THARME, R.; TOCKNER, K.; TSEGAI, D. Environmental flows and water governance: Managing sustainable water uses. Current Opinion in Environmental Sustainability, v. 5, n. 3-4, p. 341-351, 2013. http://dx.doi.org/10.1016/j.cosust.2013.06.009.

POFF, N. L.; ALLAN, J. D.; BAIN, M.; KARR, J.; PRESTEGAARD, K.; RICHTER, B.; SPARKS, R.; STROMBERG, J. The natural flow regime. Bioscience, v. 47, n. 11, p. 769-784, 1997. http://dx.doi. org/10.2307/1313099.

SEI - STOCKHOLM ENVIRONMENT INSTITUTE. Water Evolution and Planning: WEAP. User guide. Estocolmo; 2011.

SOUZA, C.; AGRA, S.; TASSI, R.; COLLISCHONN, W. Desafios e oportunidades para a implementação do hidrograma ecológico. Revista de Gestão de Água da América Latina, v. 5, n. 1, p. 25-38, 2008.

THARME, R. E. An overview of environmental flow methodologies, with particular reference to South Africa. In: KING, J. M.; THARME, R. E.; VILLIERS, M. S. Environmental flow assessments for rivers: manual for the Building Block Methodology. Pretoria: Water Research Commission, 2000. p. 15-40. Report T'T 131/00.

YANG, N.; MEI, Y.; ZHOU, C. An optimal reservoir operation model based on ecological requirement and its effect on electricity generation. Water Researches Management, v. 26, n. 14, p. 4019-4028, 2012. http://dx.doi.org/10.1007/s11269-012-0126-x.

\section{Authors contributions}

Micol Brambilla: Simulation of the hydric system; analysis of the results.

Andrea Sousa Fontes: Determination of the method of analysis; assistance in mathematical modeling; supervision of the research.

Yvonilde Dantas Pinto Medeiros: Analysis of context; assistance in method determination; co-working in the analysis of the results; supervision of the research. 